\title{
Are primary education teachers from Catalonia (Spain) trained on ICT and disability?
}

\author{
Dr. José María Fernández Batanero \\ batanero@us.es \\ University of Seville, Spain \\ Dr. Pedro Román Graván \\ proman@us.es \\ University of Seville, Spain
}

Dra. Carmen Siles Rojas

csiles@us.es

University of Seville, Spain

\begin{abstract}
In this work, we present the results of a study that had as an objective to understand the perception of key informants (directors, heads of studies and ICT coordinators from education centers, as well as well as directors and technology managers from teacher's training centers), on the levels of technological training and knowledge possessed by the Primary Education teachers from the Autonomous Community of Catalonia, with respect to the use of ICT with students with disabilities. For the methodology, a qualitative research design was used. The information was obtained from an analysis of 68 interviews conducted to professional from the education sector in Catalonia. The results obtained showed that the professionals perceived a low level of training and knowledge of the teachers with respect to the use of ICT with people with disabilities. The findings showed the need to design and implement didactic training that empowers the teachers.
\end{abstract}

\section{Keywords}

Information and communication technologies; functional diversity; disability; teacher's training; accessibility 


\section{Introduction}

The new technological challenges faced by current education practices have created a teacher's profile that is very different from the past. These novelties in the education sphere have opened new research topics, such as the inclusion of ICT in the classroom and their contribution to the development of new learning contexts that take into account the individual differences of the student body. This technological inclusion goes through a set of variables: legislative, organizational, economic, etc., and indispensably, through the conception and the degree of training and mastery possessed by the teachers on these resources (Shin, 2015).

This teacher's training should be focused on granting the teachers with knowledge, skills and competencies necessary for the use of ICT, as a resource that brings together the processes of teaching-learning to all the students, including those who have special educational needs. For this reason, the present study is considered relevant, as, on the one hand, the volume of research works that deal with the teacher's training on ICT applied to disability is very scarce. And on the other hand, it is related to social aspects, where the processes of social discrimination and exclusion are highly worrisome for the families, education centers, town halls and other institutions that have an impact on the citizen's training and education. Also, it offers the direct opinion of the professional workers who are responsible for the training in Catalonia (Spain). This will enable an improvement in teachers' training and professional development.

\section{a. Theoretical foundations}

In today's society, ICT have provoked a transformation in the manner in which the school system should integrate these tools in order to improve the processes of teaching and learning. Despite this, their addition continues being a challenge, as their maximum pedagogic potential has yet to be reached. An example of this is the training model offered by different institutions, as well as the use given to these technologies by the teaching staff. In this line, the twenty-first century teachers must face a multitude of tasks during their professional practice related to planning, intervention, communication or updating (Carrera \& Coiduras, 2012); and they must be competent in using technology in all of these areas. Teachers face the challenge of demanding skills not only for the use of computer tools, but also for teaching about how to use them practically. In addition, they must have enough competence to provide the pedagogical use of these devices to enhance student learning in all disciplines (Güne \& Bahçivan, 2018).

Thus, both initial and ongoing training is shaped as a key element, hence the involvement of different educational institutions nationally. In the case of the Catalan context, the Education Department of the Catalonian Government has been proposing, under different approaches, a rubric to guide the process for assessing the digital teaching competence of pre-service and inservice teachers. There have been several studies that highlight the need to develop and promote investigations in this area (Esteve, 2015).

In the Spanish case, the latest studies point to the fact that teachers have certain mastery on the technical aspects, but they do not use technology in the classroom, as this requires skills that are more pedagogic than instrumental in nature (Tello \& Cascales, 2015). In the catalonian context, many studies have shown how important teacher training is for the integration of ICT into teaching practices (Esteve, 2015; Gisbert, González \& Esteve, 2016).

In the international arena, the volume of production of research works related to the integration of technology into the classroom are abundant (Hu \& Yelland, 2017; Hatlevik, 2017), as well as works that recognize the benefits provided by ICT to students with special education needs (Turner- 
Cmuchal \& Aitken, 2016; Alper \& Goggin, 2017; Hollier, 2017). Nevertheless, one of the problems that needs addressing, so that ICT can reach all of the students, including those who have a disability, is the training of the teachers. Research on the efficacy of teacher's training and ICT show that the type of training offered (courses, seminars, etc.), besides being scarce, does not result in changes in the teaching activity (Hu \& Yelland, 2017).

This inappropriate use of ICT by the teachers in the classroom is exacerbated if we take into account the barriers that block the training of the teachers. There are diverse research studies that bring to light factors that impede the implementation of ICT in school centers, highlighting those that refer to extrinsic barriers (lack of time, resources and funding for the training) and the intrinsic barriers (attributed to the teacher's attitude) (González \& De Pablos, 2015; Villalba, González-Rivera \& Díaz-Pulido, 2017).

However, if we discuss ICT competencies needed for their use with people with disabilities, we can verify the low volume of existing works, although they also highlight they lack of training and knowledge possessed by the teachers with respect to the types of technologies that can be used with this collective, the possibilities they offer, and the function for which they can be used for (Tello \& Cascales, 2015; Morales \& Llorente Cejudo, 2016; Fernández Batanero \& Rodríguez Martín, 2017). This aspect has negative repercussions for the use of ICT, impeding the accessibility of the information and the enhancing of the people's abilities, and in the case of people with disabilities, helping to alleviate their difficulties or reducing them to a minimum (Orozco, Tejedor \& Calvo, 2017).

Definitely, technologies can be useful for learning in an inclusive education setting. Authors such as Forian (2004) argue that ICT have the potential to be an effective leveller for people with disabilities. This idea has important implications for these students, since technology assists in creating the conditions for equal learning opportunities, as well as facilitating access to the curriculum.

\section{Purpose and research question}

The main objective of this study was to understand the perception of key informants (directors, heads of studies, and ICT coordinators from educational centers, as well as directors and technology managers from teacher's training centers), on the degree of training and technological knowledge possessed by the teachers of Primary Education from the Autonomous Community of Catalonia, with respect to the use of ICT with students with disabilities. More specifically, the research questions which will be used to answer this objective are:

RQ1: Are Primary Education teachers from the Community of Catalonia sufficiently prepared and aware for the use and application of ICT with people with disabilities?

RQ2: Does the province and type of education center condition the level of competency of the teachers for the use of ICT with students with disabilities?

RQ3: What factor shinder the promotion and development of teaching experiences on the use of ICT with students with disabilities? 


\section{Method}

Given the nature of the objectives set, a qualitative methodology was used, underpinned by an interpretative paradigm perspective, and from an ontology and epistemology that are clearly naturalistic. More specifically, the interpretative approach was based on the method of Grounded Theory, proposed by Glaser \& Strauss (1967).

\section{a. Participants}

In this research, 68 professional workers from the education sector participated. The selection of the elements was conducted according to natural group units, which in our case were comprised by provinces and types of center. Therefore, the object of the study were public $(\mathrm{PbC})$, private $(\mathrm{PC})$ and semi-private centers (SPC), as well as teaching training centers (TTC from here on), located in the 4 provinces from the Community of Catalonia.

\begin{tabular}{lcccc}
\hline Province & TTC & PbC & SPC & PC \\
\hline Tarragona & $17 \%($ Fr10) & $66 \%(F r 48)$ & $17 \%(F r 10)$ & $0 \%$ \\
\hline Girona & $25 \%$ & $33.3 \%$ & $33.3 \%$ & $33.3 \%$ \\
\hline Barcelona & $25 \%(F r 17)$ & $25 \%(F r 17)$ & $0 \%$ & $50 \%(F r 34)$ \\
\hline Lerida & $25 \%(F r 17)$ & $50 \%(F r 34)$ & $25 \%(F r 17)$ & $0 \%$ \\
\hline Total & $17.6 \%(F r 11)$ & $41.2 \%(F r 28)$ & $23.6 \%(F r 18)$ & $17.6 \%(F r 11)$
\end{tabular}

Table 1 . Distribution of provinces and type of center.

The distribution of the participants was the following: from the total sample, $35 \%$ corresponded to directors from educational centers, $35 \%$ referred to heads of study, $12 \%$ were ICT coordinators, $6 \%$ were directors from teacher training centers, and $12 \%$ were technology consultants from teacher training centers. Lastly, $29 \%$ of the informants were men and $71 \%$ were women.

\section{b. Instruments}

The technique used for the gathering of data was the semi-structured interview. In order to validate it, the expert judgement strategy was utilized through the use of the Delphi method. This was conducted through a document annexed to the interview, with a series of open-ended questions, and which was given to eight specialists selected in a double process: first of all people were selected with the following criteria: have professional experience in the educational use of ICT, have experience in Special Education, have experience in the use of ICT for people with disabilities, teach ICT applied to education or in special education, or work in an institution related to special education. Secondly, the coefficient of expert competence was applied for its definitive selection, a coefficient that is calculated "from the opinion shown by the expert regarding his level of knowledge about the research problem, as well as the sources that allow him to argue the established criterion... The coefficient is obtained by applying the following formula: $K=1 / 2(K c+$ Ka)" (Cabero \& Barroso, 2013: 29).

\section{c. Procedure}

Interviews were conducted during the first three months of 2018, by telephone and scheduled appointment. All interviews were recorded in audio with the interviewee's authorization. The average duration was about 20 minutes. The interview script contained questions such as: What benefits do you think Information and Communication Technologies (ICT) provide to people with disabilities? Why? Do you consider that primary school teachers are aware and qualified to help students with specific disabilities (visual, hearing, motor or cognitive ...) to use technical support 
and ICT applications? Are training experiences being carried out in schools to apply ICT to students with disabilities?

After the process of transcribing the interviews, a reduction of data and its relevant codification was carried out with the help of the software Atlas.ti (version 6.2), based on a system of categories derived from the dimensions of the interview script and the analysis process itself. We need to point out that we have made limited use of the software, focusing only on the coding and retrieval functions of the texts. We must say that the elaboration of the categories and the decision to take the answers of the interviewees as correct or incorrect have been submitted to criteria of concordance and reliability. This means that the analysis carried out, both for the process of constructing the category system (concordance between code writers) and the moment in which the code writers have used this category system (reliability), resulted in an excellent kappas coefficient above 0.75 (Fleiss, 1981).

\begin{tabular}{cccc}
\hline Interview & Kappa & Agreement (\%) & Disagreement (\%) \\
\hline 1 & .96 & 98.71 & 1.29 \\
\hline 3 & .92 & 98.74 & 1.26 \\
\hline 5 & .97 & 99.38 & 0.62 \\
\hline 7 & .96 & 98.56 & 1.44 \\
\hline 9 & .95 & 98.73 & 1.27 \\
\hline 11 & .98 & 99.35 & 0.65 \\
\hline 13 & .95 & 98.03 & 1.97
\end{tabular}

Table 2. Cohen's Kappa index for unpaired interview.

The categories selected for the study revolved around: socio-demographic aspects (type of center, province, professional position in the center [position], gender and time at present position); concept of functional diversity; concept of disability; ICT benefits for people with disability; awareness and preparation of the teachers; development of training experiences; promotion of the training; barriers to the development of training plans; priority for training (Table 3).

\begin{tabular}{|c|c|c|}
\hline Categories and definition & Sub-categories & Examples \\
\hline \multirow{2}{*}{$\begin{array}{l}\text { Functional diversity } \\
\text { concept: Differences in a } \\
\text { person's functioning to } \\
\text { carrying out daily activities } \\
\text { (moving around, reading, } \\
\text { catching, speaking, } \\
\text { interacting, etc.) in a } \\
\text { different manner from the } \\
\text { general population } \\
\text { (Independent Living Forum, } \\
\text { 2005). }\end{array}$} & \multirow[b]{2}{*}{$\begin{array}{l}\text { Interviewees' } \\
\text { knowledge of the } \\
\text { functional diversity } \\
\text { concept. }\end{array}$} & $\begin{array}{l}\text { Right answer: "Functional diversity is an } \\
\text { alternative term to disability. It is more } \\
\text { inclusive (ENTRE.19)." }\end{array}$ \\
\hline & & $\begin{array}{l}\text { Wrong answer: " These are the different } \\
\text { ways we have to access ICT or the whole } \\
\text { knowledge (ENTRE.16)". }\end{array}$ \\
\hline \multirow{2}{*}{$\begin{array}{l}\text { Disability concept: a } \\
\text { broad term that includes } \\
\text { deficiencies, activity } \\
\text { limitations, and participatory } \\
\text { restrictions (World Health }\end{array}$} & \multirow{2}{*}{$\begin{array}{l}\text { Interviewees' } \\
\text { knowledge of disability } \\
\text { concept. }\end{array}$} & $\begin{array}{l}\text { Right answer: "Students with special } \\
\text { educational needs (ENTRE.056)." }\end{array}$ \\
\hline & & $\begin{array}{l}\text { Wrong answer: "Students who due to } \\
\text { some factors do not achieve the } \\
\text { minimum standards established by the }\end{array}$ \\
\hline
\end{tabular}




\begin{tabular}{|c|c|c|}
\hline Organization (WHO), 2001). & & curricula (ENTRE.155)". \\
\hline \multirow{6}{*}{$\begin{array}{l}\text { ICT benefits for people with } \\
\text { disabilities: Improvement } \\
\text { experienced by a person } \\
\text { thanks to something that is } \\
\text { done to him or her or } \\
\text { something that is given to } \\
\text { him or her. }\end{array}$} & - $\quad$ Accessibility & $\begin{array}{l}\text { "Allows them to access education" } \\
\text { (INTER.026) }\end{array}$ \\
\hline & - $\quad$ Autonomy & $\begin{array}{l}\text { "Favors personal autonomy when solving } \\
\text { everyday problems and procedures" } \\
\text { (INTER.69). }\end{array}$ \\
\hline & $\begin{array}{l}\text { - } \quad \text { Communication } \\
\text { and expression. }\end{array}$ & $\begin{array}{l}\text { "[...] Be able to communicate and be able } \\
\text { to communicate with them, so they can } \\
\text { express themselves and so that they can } \\
\text { see everything they can do with other } \\
\text { resources" (INTER.034). }\end{array}$ \\
\hline & $\begin{array}{l}\text { - } \text { Facilitates } \\
\text { learning }\end{array}$ & $\begin{array}{l}\text { "Facilitate individual work respecting the } \\
\text { student's rhythm" (INTER.050). }\end{array}$ \\
\hline & - Integration & $\begin{array}{l}\text { "I think it is a way out that makes them } \\
\text { become more integrated, and helps them } \\
\text { with inclusion" (INTER.032). }\end{array}$ \\
\hline & Motivation & $\begin{array}{l}\text { "Stimulate motivation and self-esteem } \\
\text { when giving them successes that were } \\
\text { difficult to obtain before" (INTER.17). }\end{array}$ \\
\hline \multirow{3}{*}{$\begin{array}{l}\text { Teacher's awareness and } \\
\text { preparation: } \\
\text { Awareness: Perception of } \\
\text { the interviewees on the } \\
\text { question of if the primary } \\
\text { education teachers are } \\
\text { aware of the importance of } \\
\text { attending training activities. } \\
\text { Preparation: Teacher's level } \\
\text { of training. }\end{array}$} & $\begin{array}{l}\text { - Awareness and } \\
\text { preparation }\end{array}$ & $\begin{array}{l}\text { "Aware yes, very much so and especially } \\
\text { the primary education teachers, but the } \\
\text { world of New Technologies changes so } \\
\text { often that we become obsolete in no } \\
\text { time" (INTER.045). }\end{array}$ \\
\hline & $\begin{array}{l}\text { - } \quad \text { Aware yes, } \\
\text { prepared no }\end{array}$ & $\begin{array}{l}\text { "I think aware yes, but prepared no. } \\
\text { There are many teachers who have to be } \\
\text { trained and they have to upgrade/ } \\
\text { themselves on the use of new } \\
\text { technologies" (INTER.33). }\end{array}$ \\
\hline & $\begin{array}{l}\text { Neither aware } \\
\text { nor prepared }\end{array}$ & $\begin{array}{l}\text { "From my point of view, the teachers } \\
\text { lack awareness, but training overall" } \\
\text { (INTER.20). }\end{array}$ \\
\hline \multirow{2}{*}{$\begin{array}{l}\text { Development of training } \\
\text { experiences: Training } \\
\text { activities prepared and } \\
\text { developed in the Primary } \\
\text { Education schools. }\end{array}$} & \multirow{2}{*}{$\begin{array}{l}\text { Development or not of } \\
\text { training experiences in } \\
\text { the Primary Education } \\
\text { schools. }\end{array}$} & $\begin{array}{l}\text { "Yes, we have a work group on New } \\
\text { Technologies, and we have a special } \\
\text { education work group. Each time there } \\
\text { is a new tool related with ICT and } \\
\text { attention to diversity, an exchange of } \\
\text { information is conducted between the } \\
\text { two work groups" (INTER.029). }\end{array}$ \\
\hline & & $\begin{array}{l}\text { "No, because the training is solicited } \\
\text { according to the improvement proposals } \\
\text { by the co-workers at the school, then, as } \\
\text { a director, I take charge in managing } \\
\text { what they ask for" (INTER.011). }\end{array}$ \\
\hline \multirow[t]{2}{*}{$\begin{array}{l}\text { Barriers for the development } \\
\text { of training plans: Obstacle } \\
\text { that impedes or makes } \\
\text { difficult the creation of } \\
\text { training activities. }\end{array}$} & $\begin{array}{l}\text { Teacher's } \\
\text { attitude }\end{array}$ & $\begin{array}{l}\text { "The barriers are, fundamentally, of } \\
\text { personal character. From those teachers } \\
\text { that are not implicated, or are not in } \\
\text { agreement" (INTER.066). }\end{array}$ \\
\hline & - Quality of & "The training of the professionals within \\
\hline
\end{tabular}




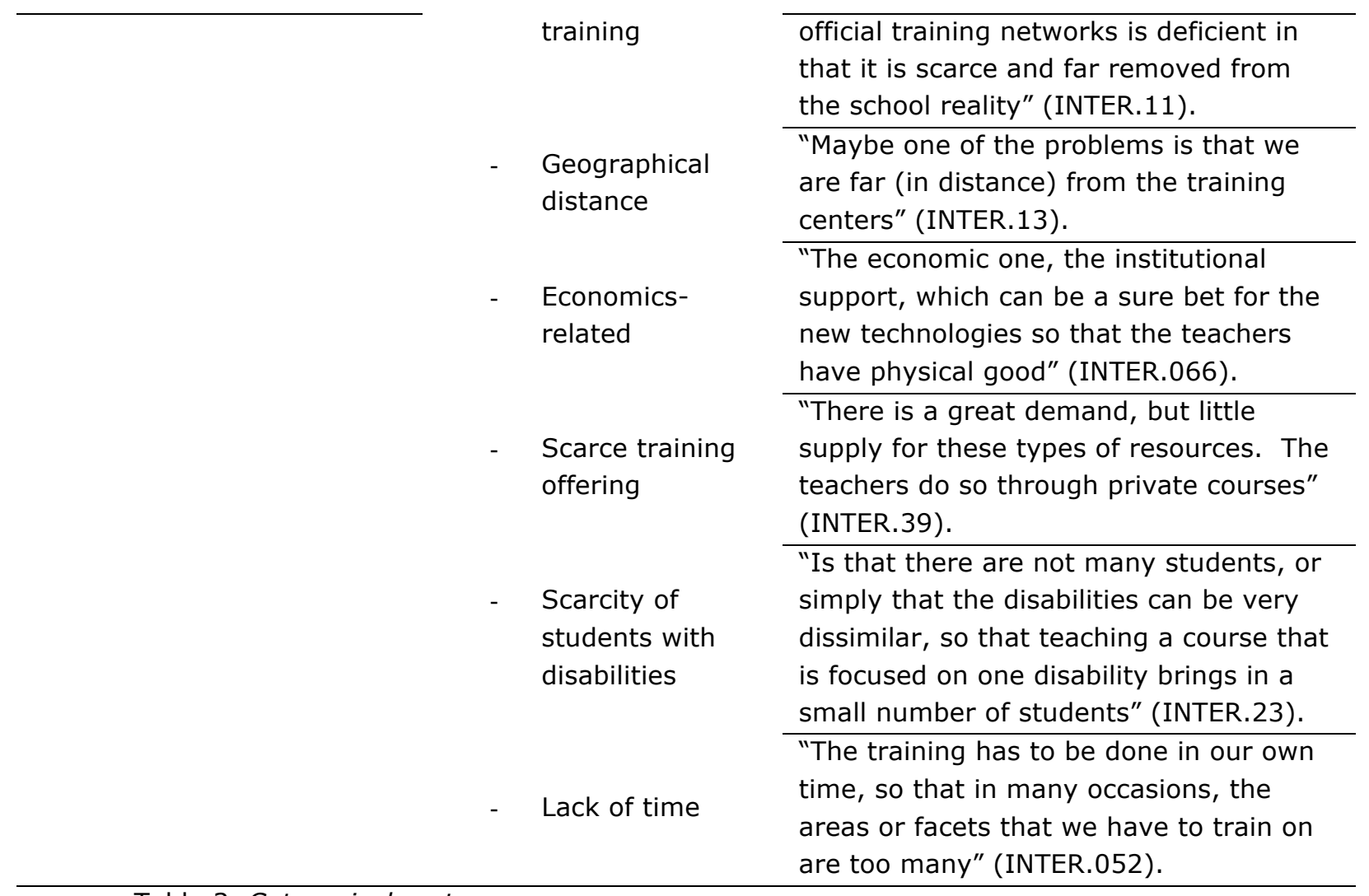

Table 3. Categorical system.

\section{Results}

Next, the conceptual network which shows the list of categories with their corresponding subcategories obtained after the analysis, are shown. Also, the relationship between categories is observed. 


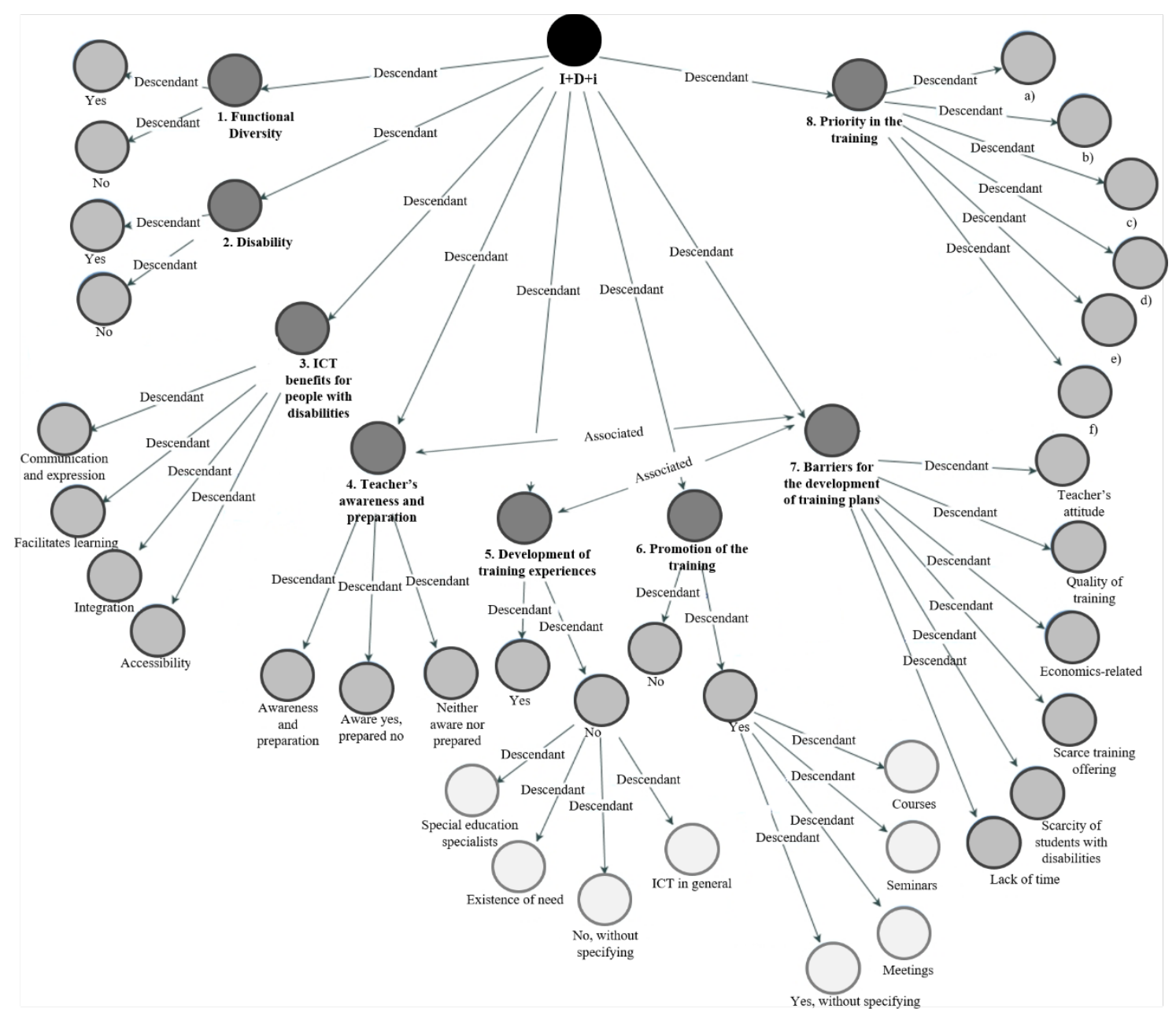

Figure. 1. Conceptual network, relationship between categories and sub-categories

Relying on the empirical basis of the perception of the key informants, the results obtained were:

\section{a. Functional diversity and concept of disability}

In first place, it is important to point out that most of those interviewed (78\%) were unaware about the concept of functional diversity. Also, it is striking to verify that, as shown in table 3 , the difficulty in defining the term was general for all the Catalonian provinces and all the education centers. For both variables, the percentage of incorrect answers surpassed $65 \%$, and it even reached $85.7 \%$ of wrong answers in the case of the Preschool and Primary Education Centers $(\mathrm{PbC})$. In spite of this, when analyzing the variable "position", it should be highlighted that only ICT consultants from the Teacher training centers (TTC) surpassed $50 \%$ of correct answers related to the concept of functional diversity. Lastly, from the total number of participants, only $33 \%$ of the women answered correctly. Regarding the participants, the counsellors of Teacher Training Centers present the greatest challenge to establish the functional diversity term (15\%), while the Heads of Studies present the greatest knowledge.

As for the results referring to the concept of disability, the results obtained showed that the key informants did possess knowledge and were able to define the term disability $(71 \%)$, independently of the variables "province" and "type of center". 


\section{b. ICT benefits for people with disabilities}

Despite those interviewed not having specific training in regards to the student's disability, it should be mentioned that the participants recognized, in a precise manner, the benefits provided by these technological tools to these students. Although the possible benefits are all related, we would like to point out that the most frequently cited are those that refer to "facilitating learning" and "accessibility" for all students. The high percentage of appearance of the sub-categories "accessibility" and "facilitates learning" was shared by all interviewees:

"The technologies are very useful because they allow the children to be able to do things that they could not due otherwise" (INTER.12).

Likewise, the importance of the "integration" of the students with disabilities thanks to the use of ICT tools was underlined.

"It is well known that ICT can be a powerful way to integrate students. Not only to those with special educational needs due to disability, but also for other reasons". (INTER. 34)

\section{c. Teacher's awareness and preparation}

The previously-mentioned results brought to light, even more so, the need for a greater and more specific training on disabled students and ICT in general. In fact, when those interviewed were asked if they considered the Primary Education teachers to be sufficiently prepared and aware to work with disabled students, $53 \%$ of the key informants recognized that they were aware, but not prepared.

The reasons that re-enforce this scarce level of preparation are related to aspects such as: the teacher's age; the fast updating/changing of technological tools; lack of interest by the teacher; obsolete means and resources and subject-matter that is only related with specialized teachers (therapeutic pedagogy or hearing and language):

"At the general level, I don't think we are prepared. Also, we work at a center where the teachers are 45 years old on average, and the initial training we received was more focused on knowledge than in the different ways to tend to diversity, meaning, to make sure they become aware of it" (INTER.43).

"ICT evolve quickly, and the teachers must be motivated for using them for adaptive aims. For this, there are specific teaching staff that are specialized in special education. Nevertheless, the new generations already have an advanced phase on the use of ICT, and I sense that the initial training of the teachers is directed to their development, or it should be (INTER.20).

In the analysis of the category "awareness and preparation of the teachers", the results obtained as a function of the provinces varied considerably. While in the province of Girona $67 \%$ of the informants recognized that the Primary Education teachers were aware and prepared to work with disabled students by using ICT, in the province of Barcelona $75 \%$ of the participants attested that the primary school teachers were aware but not prepared. In the provinces of Tarragona and Lerida, the scale was balanced between those who were aware, but not prepared, and those who were neither aware nor prepared (50\%).

As for the relation of the type of education center, as shown in figure 2, the centers that obtained a higher percentage of awareness and preparation on the use of ICT with disabled students, were the 
private ones (67\%). In turn, the responses from the informants who belonged to the TTC are highlighted, considering that the primary school teachers, although aware, were not prepared to help the disabled students to use ICT (100\%) (See figure 2 ).

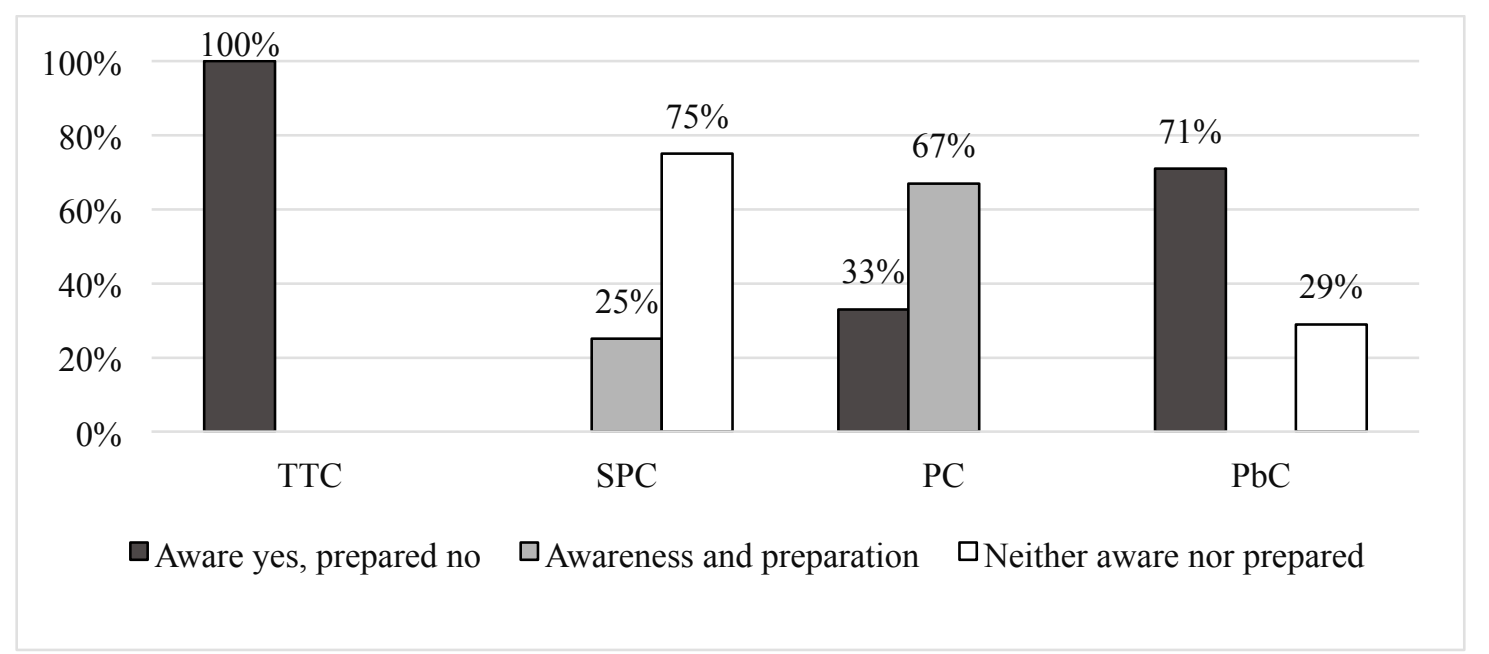

Figure. 2. Percentage obtained on the level of awareness and preparation of the teachers according to the type of center. TTC (Teacher Training Center); PbC (Public Center); SPC (Semi-private School); PC (Private Center)

\section{d. Development of training experiences}

The key informants from the Community of Catalonia (67\%) recognized that the training was scarce or too general, as opposed to the $33 \%$ who thought otherwise. This means that the low number of training activities conducted were focused on the use of ICT in general, without taking into account the students with disabilities. Also, they ensured that this training should only be conducted by specialized teachers, and that the centers did not count with a great number of students with disabilities:

"The courses that are available on the use of ICT with the disabled are very few, not to say almost non-existent, so that new training experiences cannot be conducted in the centers, although in many cases the faculty and the orientation team ask for it, the demand that the TTC receives is low" (INTER.49).

As for which provinces conducted more or less training experiences, it should be pointed that in the province of Barcelona, $75 \%$ of those interviewed attested to having conducted training experiences, while those in Tarragona (33\%), Girona (0\%) and Lerida $(23 \%)$, the informants ensured that the training was scarce:

"Yes, they are promoted by the department of education of Catalonia, but what happens is that the training sessions are voluntary. Each teacher trains according to the curriculum they want to have or what the center needs, but it is not compulsory. What is compulsory is taking a course, but it is not compulsory to choose a specific course" (INTER. 62).

Lastly, we consider it important to know which centers conducted the least number of training activities on ICT and disability. In this sense, the informants from the TTCs, the semi-private centers and the public centers were the ones that ensured the inexistent offerings or the conducting of these training experiences. 


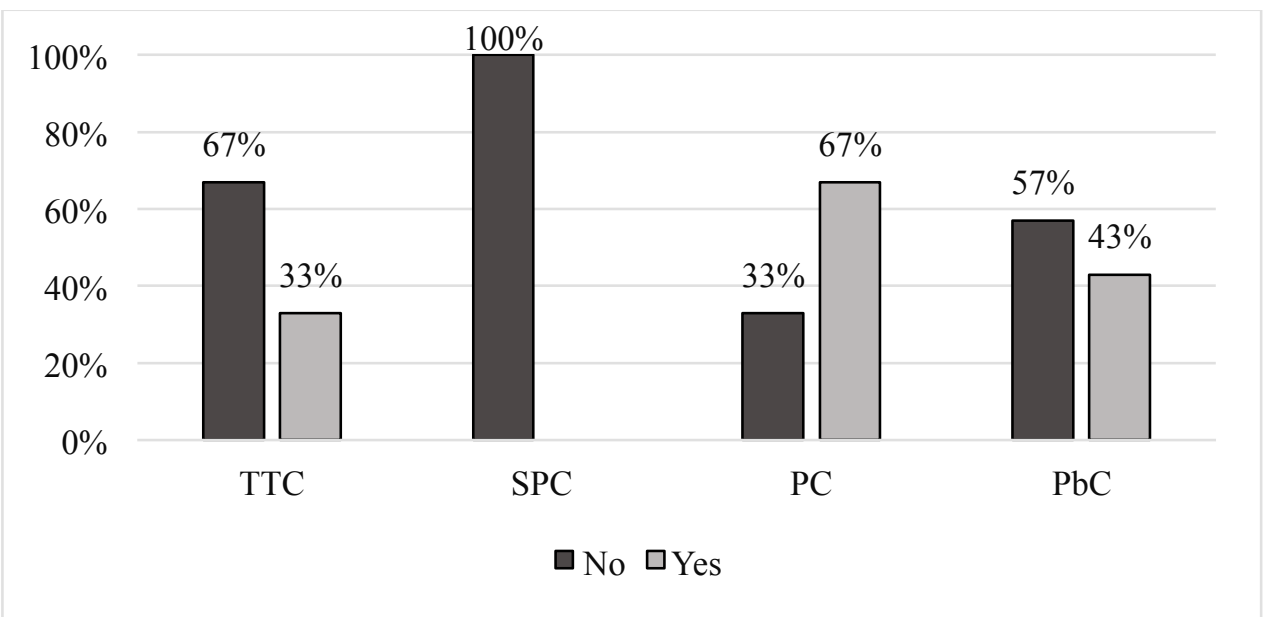

Figure. 3. Percentage of development of training experience according to type of center.TTC (Teacher Training Center); PbC (Public Center); SPC (Semi-private School); PC (Private Center)

Together with the results shown in Figure 3, it should also be noted that the development of training activities on the subject of ICT and disability also depended on how long the key informants had been in their present position in the center. Thus, the interviewees with less teaching experience acknowledge that schools do not provide training related to ICT and disability. Meanwhile, interviewees with more than 11 years of teaching experience consider that this type of training is developed.

\section{e. Promotion of the training}

The high percentage obtained $(88 \%)$ verifies that the education centers and teacher training centers promoted and tried to offer, through different means, training activities for the Primary Education teachers. Among the training activities we highlight three courses, seminars and meetings. We understand seminar as meetings where a specific topic is developed in depth, including teaching and updating teaching issues. Courses are both more formal and theoretical, extending over time.

Based on the results obtained, a tendency was denoted towards the conducting of course, underlining those that dealt with ICT in general, and others that specified the use of ICT with students with disabilities. Likewise, the conducting of seminars and/or meetings in which the teachers were informed about all the activities that were publis hedwas highlighted, as information was divulged or knowledge was shared about the subject matter:

"They (courses) are promoted in different ways. This year, we've had training at the level of ICT for the entire staff, so that they learn how to better use the new technologies as related to the digital blackboards, and also, we get in touch with different businesses that occasionally provide us with courses, software and different materials" (INTER. 22).

The public schools include the largest number of training activities, followed by the subsidised private schools. Despite this, very few training activities are carried out taking into account ICT as a support for students with disabilities. 


\title{
f. Barriers for the development of training plans
}

According to the interviewees, the factors that hinder the performance of training activities related to ICT and disability are variable, but among them six main ones stand out (Table 4)

\begin{tabular}{ll}
\hline SUBCATEGORY & $\%$ \\
\hline Teacher's attitude & $11.1 \%$ \\
\hline Geographical distance & $3.7 \%$ \\
\hline Economic & $55.6 \%$ \\
\hline Scarce training offerings & $3.7 \%$ \\
\hline Scarcity of students with disabilities & $3.7 \%$ \\
\hline Lack of time & $22.2 \%$
\end{tabular}

Table 4. Percentage of barriers that make difficult the conducting of training activities.

Among the barriers that made the training more difficult, we found factors such as "economics" $(55.6 \%)$, "lack of time" (22.2\%) and the "teacher's attitude" (11\%). In this regard, expressions such as the following were found by principals and heads of studies.

\begin{abstract}
"There are little resources at the centers for teachers. Also, as it is a semi-private center, the teachers from the semi-private centers remain a bit behind those from the public centers, and also, overall, the complexity of these courses, which are costly, do not garner enough attention" (INTER. 18).
\end{abstract}

"The only handicap that I see is that we have recycled ourselves in so many things that we do not have enough time to do it" (INTER. 08).

"The barrier we find is that there are teachers who are not involved or who do not agree" (INTER. 33).

The economic barriers and the lack of time were shared by all by all interviewees, whatever role they play.

Among the results we highlight that both principals of Teaching Training Centres and ICT coordinators agree that one of the obstacles is teachers' lack of motivation, resulting in no demands for such training.

"Many of the training activities come from the demands of the teachers themselves. The problem may be the scarce demand" (INTER. 4)

Next, and in order to solve the problems brought on by the development of training experiences on ICT used with people with disability, various affirmations are shown that deal with aspects that should be taken into account in the training activities directed towards Primary Education teachers. The participants were given the possibility of choosing the three statements they considered to be a priority for the training of the teachers. Among the most relevant results, those interviewed considered a priority that the training activities facilitate the work of "knowing how to apply didactic strategies and curricular adaptations supported by ICT" $(33 \%)$, that favor being able to "find websites with educational resources for the students with disabilities" (25\%), as well as "to know about specific technological materials for the students with disabilities" (16\%). 
It is also appropriate to highlight that the statement "know institutions related with the accessibility to websites" was selected the least ( $2 \%)$.

The elements that should be included in the teacher's training were similar in every province. Nevertheless, in the province of Tarragona, those interviewed highlighted (22\%) the selection of the statement "to successfully adapt a computer system" to the needs of any person with a disability.

Lastly, we would like to add that as a function of the type of center, the results did not allow us to establish differences, as the percentage of selection of the statements was similarly maintained in each of the centers.

\section{Discussion and conclusions}

The conclusions derived from the previous data, and as related to the research questions, revealed aspects such as:

RQ1: Are Primary Education teachers from the Community of Catalonia sufficiently prepared and aware for the use and application of ICT with people with disabilities?

The professional workers interviewed perceived a low level of training and knowledge of the Primary Education teachers with respect to the use of ICTwith people with disabilities. These findings coincided with those from the works by Suriá, Martínez \& Ordoñez (2014), Tello \& Cascales (2015), Morales \& Llorente Cejudo (1916), Fernández Batanero \& Rodriguez Martín (2017). In spite of this, the lack of training has not impeded that the interviewed recognize the benefits provided by ICT to students with disabilities (Turner-Cmuchal \& Aitken, 2016; Alper \& Goggin, 2017; Hollier, 2017), although they did recognize the scarce level of awareness of the teachers on the use of ICT with students with disabilities. From this perspective, it should be pointed out that the trust and education that the disabled student will receive are intimately linked to the training possessed by the teacher on the subject. Hence, there lies the need for promoting education policies on the initial and permanent training of the teachers that include in the study plans, the educational use of ICT within the contexts of training, as well as those that are dedicated to analyzing the educational possibilities of ICT for people with disabilities. This training should facilitate the creation of learning environments in accordance to the reality of the center, the teacher's demands, and mainly, the student's characteristics.

RQ2: Does the province and type of education center condition the level of competency of the teachers for the use of ICT with students with disabilities?

The province where the teaching takes place conditions the level of competency of the teachers for the use of ICT with students with disabilities. In this sense, despite the fact that the lack of training was found in all of them, the results were higher in the provinces of Tarragona and Lerida. Likewise, this low level of training was found independently of the education center where the teachers taught, although the semi-private centers were more predominant.

RQ3: What factors hinder the promotion and the development of teaching experiences on the use of ICT with students with disabilities?

The lack of implementation of training plans conditioned the promotion and developments of 
experiences. This scarce training was promoted by the education centers and the teacher training centers through two main ways. On the one hand, the conducting of courses, and on the other, through seminars and/or meeting where the teachers were informed about all the activities that were published, and where information was divulged or knowledge was shared about the subject.

The training received denoted the great insufficiency in the provinces of Girona, Tarragon and Lerida. Likewise, it should again be noted that the semi-private education centers were the ones that conducted the least number of training activities. Following this idea, it was verified that the main factors that obstructed the development of training experiences on ICT and disability in most of the provinces were determined by economic, time and teacher's attitude factors. This finding is in agreement with those obtained by Bingimlas (2009), González \& De Pablos (2015) and Villalba, González-Rivera \& Díaz-Pulido (2017).

In the public and private centers, the main barriers observed were determined by "economic" and "lack of time" factors. Also, in the semi-private centers and the teacher training centers, besides the aforementioned barriers, the barrier "teacher's attitude" was also found.

As for the priority in the training, it was considered necessary that the training activities: facilitate the work of applying didactic strategies and curricular adaptations supported with ICT, facilitate the finding of websites with educational resources for people with disabilities and lastly, favor knowing about technological materials that are specific for working with this type of student. Ultimately, it was verified that there was a need for a training activity that included all the elements (materials, software, application of strategies and adaptation, websites, adapting of computer systems and accessible institutions).

\section{a. Implications for Practice}

As future research lines, the following are proposed: to conduct "good-practices" studies on the addition and use of ICT with people with disabilities using data gathering techniques such as nonparticipant observation and in-depth interviews; to expand the pool of informants to include the teachers themselves; and to delve into the specific problems the teachers have for using ICT with disabled persons.

\section{Acknowledgements}

The work was financed by the Spanish Ministry of Economics and Competitiveness within the State Plan for the Development of Scientific and Technical Research of Excellence 2013-2016 (DIFOTICYD EDU2016 75232-P).

\section{Statements on open data, ethics and conflict of interest}

The data described in this article contains no personal, or personally identifiable information and are not accessible to other researchers as per written agreement with participants and ethical approval. There is no conflict of interest regarding this work. 


\section{References}

Alper, M. \& Goggin, G. (2017). Digital technology and rights in the lives of children with disabilities. New Media y Society, 19(5), 726-740. doi: https://doi.org/10.1177/1461444816686323

Bingimlas, K. A. (2009). Barriers to the Successful Integration of ICT in Teaching and Learning Environments: A Review of the Literature. Euroasia Journal of Mathematics, Science \& Technology Education, 5(3), 235-245.

Cabero, J. \& Barroso, J. (2013). La utilización del juicio de experto para la evaluación de TIC: el coeficiente de competencia experta. Bordón, 65(2), 25-38.

Carrera, F. X. \& Coiduras, J. L. (2012). Identificación de la competencia digital del profesor universitario: Un estudio exploratorio en el ámbito de las ciencias sociales. REDU. Revista de Docencia Universitaria, 10(2), 273-298.

Esteve Mon, F.M. (2015). La competencia digital del futuro docente: análisis de su autopercepción y evaluación de su desempeño por medio de un entorno 3D (Doctoral dissertation). Tarragona: Universitat Rovira i Virgili.

Fleiss, J. L. (1981). Statistical methods for rates and proportions. New York: John Wiley and Sons.

Florian, L. (2004). Uses of technology that support pupils with special educational needs. In L. Florian \& J. Hegarty (Eds.), Ict and special educational needs. Maidenhead, UK: Open University Press.

Fernández Batanero, J. M., Cabero, C. \& López, E. (2018). Knowledge and Degree of Training of Primary Education Teachers in Relation to ICT Taught to Students With Disabilities. British Journal of Educational Technology, 50(4), 1961-1978. doi: https://doi.org/10.1111/bjet.12675

Fernández Batanero, J. M. \& Rodriguez Martín, A. (2017). TIC y Diversidad Funcional: conocimiento del profesorado. EJIHPE: European Journal of Investigation in Health, Psychology and Education, 7(3), 157-175.

Gisbert, M., González, J. \& Esteve, F. (2016). Competencia digital y competencia digital docente: una panorámica sobre el estado de la cuestión. RIITE. Revista Interuniversitaria de Investigación en Tecnología Educativa, 0, 74-83. doi: https://doi.org/10.6018/riite/2016/257631

Glaser, B. \& Strauss, A. (1967). The discovery of grounded theory: strategies for qualitative research. New York: Aldine Publishing Company.

González, A. \& De Pablos, J. (2015). Factors that hamper ICT integration at classroom. Revista de Investigación Educativa, 33(2), 401-417. doi: https://doi.org/10.6018/rie.33.2.198161

Günes, E. \& Bahçivan, E. (2018). A mixed research-based model for pre-service science teachers' digital literacy: Responses to 'which beliefs' and 'how and why they interact'. Questions, Computers \& Education, 118, 96-106. doi: https://doi.org/10.1016/j.compedu.2017.11.012

Hatlevik, O. E. (2017). Examining the Relationship between Teachers' Self-Efficacy, their Digital Competence, Strategies to Evaluate Information, and use of ICT at School. Scandinavian Journal of Educational Research, 61(5), 555-567.

Hollier, S. (2017). Technology, Education and Access: A 'Fair Go' for People with Disabilities. The 4th International Web for All Conference, Perth, Western Australia, 02-04. Doi: https://doi.org/10.1145/3058555.3058557

Hu, X. \& Yelland, N. (2017). An Investigation of preservice early childhood teachers' adoption of ICT in a teaching practicum context in Hong Kong. Journal of Early Childhood Teacher Education, 38(3), 257-274.

Morales, P. T. \& Llorente Cejudo, M.C. (2016). Initial training of the teaching staff on the use of Information and Communication Technologies (ICT) for the education of the disabled. Digital Education Review, 30, 123-134. Recuperado de http://revistes.ub.edu/index.php/der/article/view/14540/pdf_1 
Orozco, G. H., Tejedor, F. J., \& Calvo, M. I. (2017). Meta-Analysis on the effect of Educative Software on students with Special Educational Needs. Revista de Investigación Educativa, 35(1), 35-52. doi: https://doi.org/doi:10.6018/rie.35.1.240351

Shin, W. S. (2015). Teachers' use of technology and its influencing factors in Korean elementary schools. Technology, Pedagogy and Education, 24, 461-476. Doi: https://doi.org/10.1080/1475939x.2014.915229

Suriá, R., Martínez, D. \& Ordoñez, T. (2010). ICT, teaching and disability: do teachers feel prepare to support disabled students in the use of ICT in the classrooms? In P. Arnaiz; Ma. D. Hurtado and F. J. Soto. (Coords.) 25 Años de Integración Escolar en España: Tecnología e Inclusión en el ámbito educativo, laboral y comunitario. Murcia: Consejería de Educación, Formación y Empleo.

Tello, I. \& Cascales, A. (2015). Las TIC y las necesidades específicas de apoyo educativo. Análisis de las competencias TIC en los docentes, RIED: Revista Iberoamericana de Educación a Distancia, 18(2), 355-383.

Turner-Cmuchal, M. \& Aitken, S. (2016). ICT as a tool for supporting inclusive learning opportunities. Perspectivas Internacionales sobre la Educación Inclusiva, 8, 159-180. doi: https://doi.org/10.1108/S1479-363620160000008010

Villalba, A., González-Rivera, M. D. \& Díaz-Pulido, B. (2017). Obstacles Perceived by Physical Education Teachers to Integrating ICT. Turkish Online Journal of Educational Technology, 16(1), 83-92. 